\title{
HARVEST LABOR QUALITY AND PRODUCTIVITY: CASE STUDY OF CHERRY GROWING IN CHILE ${ }^{1}$
}

\author{
ROBERTO JARA-ROJAS ${ }^{2 *}$,ANTONIO GUERRA ${ }^{3}$, CRISTIÁN ADASME-BERRIOS ${ }^{4}$ \\ ALEJANDRA ENGLER ${ }^{5}$, RODRIGO VALDÉS ${ }^{6 *}$
}

\begin{abstract}
In Chile, the cherry tree has been one of the fastest growing and most profitable crops in the last ten years. However, increasing production costs, the scarcity of hired labor, and unfavorable exchange rates have reduced the productivity and competitiveness of the Chilean fruit sector. The aim of this article is to evaluate the harvest labor quality in cherry growing in Chile through the use of productivity indicators. A harvest labor evaluation system (HLES) was designed and four indicators were measured: Average Weight of Harvested Box, Average Daily Production per Worker, Percent of Export Fruit, and Percent of Fruit Discarded. Significant differences were found between the 2010/11 season (with the HLES implementation) and the previous seasons without HLES. The average worker yield, average weight of a filled box, and fruit quality improved, while the amount of discarded fruit decreased. Hired labor management in agriculture is crucial for improving the productivity of the fresh fruit export producers. The use of HLES and the adoption of new technologies could help to solve the competitiveness problem in the Chilean fruit sector.
\end{abstract}

Index terms: Human resource productivity, Performance indicators, Assessment, agriculture.

\section{QUALIDADE E PRODUTIVIDADE DO TRABALHO NA COLHEITA: ESTUDO DE CASO DE CEREJEIRAS QUE CRESCEM NO CHILE}

RESUMO - No Chile, a cerejeira tem sido uma das culturas de mais rápido crescimento e mais rentáveis nos últimos dez anos. No entanto, o aumento dos custos de produção, a escassez de mão de obra contratada, e taxas de câmbio desfavoráveis reduziram a produtividade e competitividade do setor de frutas no Chile. $\mathrm{O}$ objetivo deste artigo é avaliar a qualidade do trabalho na colheita em cerejeiras crescendo no Chile através da utilização de indicadores de produtividade. Um sistema de avaliação do trabalho de colheita (HLES) foi projetado e quatro indicadores foram medidos: Peso médio das caixas colhidas, produção diária média por trabalhador, percentagem de exportação de frutas, e percentagem de frutos descartados. Foram encontradas diferenças significativas entre 2010/11 (com a implementação do HLES) e das temporadas anteriores sem HLES. O rendimento médio por trabalhador, peso médio da caixa cheia, e a qualidade dos frutos melhorou, enquanto a quantidade de frutos descartados diminuiu. A administração do trabalho contratado na agricultura é crucial para melhoria da produtividade de produtores exportadores de frutas frescas. O uso do HLES e a adoção de novas tecnologias poderiam ajudar a resolver o problema de competitividade no sector de frutas chileno.

Termos para indexação: produtividade dos recursos humanos, indicadores de desempenho, avaliação, agricultura.

${ }^{1}$ (Trabalho 070-14). Recebido em: 13-02-2014. Aceito para publicação em: 01-04-2015.

${ }^{2}$ Assistant Professor, Department of Agricultural Economics, Universidad de Talca, Chile. E-mail: rjara@utalca.cl

${ }^{3}$ Department of Agricultural Sciences, Universidad Católica del Maule, Chile.

${ }^{4}$ Assistant Professor, Department of Economy and Administration, Universidad Católica del Maule, Chile. E-mail: cadasme@ucm.cl ${ }_{5}^{5}$ Asociate Professor, Department of Agricultural Economics, Universidad de Talca, Chile. E-mail: mengler@utalca.cl

${ }^{6}$ Research Associate, Department of Agricultural Economics, Universidad de Talca, Chile. Corresponding author, e-mail: rodvaldes@, utalca.cl

${ }^{*}$ Rodrigo Valdes and Roberto Jara-Rojas acknowledges partial financial support from the Chilean Commission for Scientific and Technological Research (CONICYT) and FONDECYT N ${ }^{\circ} 11121465$. 


\section{INTRODUCTION}

World cherry production has shown significant growth in the last 20 years, with a total land area of over 380,000 hectares that produces around 2.19 million tons. Major producer countries are mostly in the northern hemisphere: Turkey (428,000 metric tons), United States (412,000 metric tons), Iran (198,000 metric tons), and Italy (125,000 metric tons), which together account for $95.1 \%$ of production. The main countries in the southern hemisphere are Chile with 62,000 metric tons, Australia with 19,000 metric tons, and Argentina with 8,000 metric tons, which together represent $4.3 \%$ of world cherry production (COMTRADE, 2014). Cherry mostly is consumed as fresh fruit, and it is one of the most widely appreciated fruit for its taste, sweetness and myriad of nutrients (WANI et al., 2014). Also cherries are an important source of antioxidants and nutrients (GABRIELE et al., 2013). Fresh cherries are rich in sugar, anthocyanins, organic acids, tannins and ascorbic acid (YILMAZ et al., 2009). The health benefits of cherry have increased its demand especially in developed countries.

In Chile, the cherry tree has been one of the fastest growing fruit trees. It covers a land area of close to 17,200 hectares, and has an estimated 2015 production of 71, 000 metric tons, of which 52,000 are destined for the foreign market (ODEPA, 2014). Chile is the major producer and exporter of cherries in the southern hemisphere and the second major exporter in the world (ODEPA, 2011a). The increasing interest in cherry tree production is due to several factors: the favorable conditions of soil and climate in Chile, the high profitability of cherry crop, the high international demand, the trade liberalization, and the diversification of new markets (ROJAS et al., 2010). China is the major export destination, receiving $58 \%$ of total exports in the $2013 / 2014$ season, followed by the USA with $18.1 \%$, Hong Kong with $15.4 \%$, and Brazil with $4.9 \%$ (ODEPA, 2014).

Despite of the bright past of Chilean fruit production, currently the sector is facing competitiveness problems. The agricultural sector currently employs $10 \%$ of the total workforce of the country, and the fruit subsector accounts for $9.8 \%$ of this section (ODEPA, 2011a). The productivity of agricultural labor during the 2000-2014 period grew at an average rate of $8 \%$; however, agriculture had the lowest increase in labor productivity compared to other sectors of the national economy (ODEPA, 2014). For example, output per person employed in mining is more than 10 times that of farming activities (ODEPA, 2009). During the 1998-2008 period, the labor force in Chile grew by $28 \%$ while the agricultural labor force increased by only $5 \%$. According to Katz and Melo (2009), this situation is related to the importance of the labor item in the cost structure of fruit companies, amounting to approximately $46.5 \%$ of total production costs, and in some cases 70 or $80 \%$ (for table grapes and avocados, respectively).

The rising costs of energy and the increasing scarcity of labor have drastically reduced profitability and are endangering the viability of a large percentage of fruit orchards in Chile (RETAMALES and SEPÚLVEDA, 2011). Anderson and Valdes (2008) and Katz and Melo (2009) identified two topics that represent a risk for the competitiveness of agriculture: relative exchange rate (or appreciation of the Chilean peso) -which has decreased $26.5 \%$ over past ten years (BANCO CENTRAL DE CHILE, 2015) and the rising labor costs in the production of export products. Moreover, competitiveness is also affected by the rising price of inputs. In the last 10 years the price of urea nitrogen fertilizer increased more than 300\% (MELO and REBOLLEDO, 2008).

A trend toward increasing rigidity in demand for labor associated with the labor code could represent a risk to the survival of important crops such as berries, seeds, and major fruits. Domínguez et al. (2008) explain that the competitiveness of the fruit sector not only depends on the quality of the products or external factors like the relative exchange rate, but also on the human resources management strategy, worker training, and general work conditions of the employees. The strategies of the Chilean fruits export sector have been aimed at achieving economies of scale and optimizing production and commercial processes in order to lower costs and compete efficiently in the competitive markets (ADASME et al., 2012). However, the growing increase in production costs (labor, energy, and inputs), dollar devaluation, and the decrease of hired labor availability have jeopardized the production of cherries and other fruits, compromising the sustained rise in growth experienced in recent years. This scenario gives rise to the need to research new ways of improving the productivity of the agricultural labor force in this sector. Also, the cherry fruit requires a significant amount of labor (on average 135 workdays per hectare in the season), especially for harvesting in the months of November and December (77 workdays per hectare) (ODEPA, 2011b). The scarcity of the hired labor in this scenario is made more complex by the fact that at the same time as the cherry harvest in Chile there is also a need for labor 
for canopy management of table grapes and thinning and green pruning of stone fruits. At the same time, the blueberry harvest and the harvest some early varieties of peaches or nectarines in the central part of the country are also taking place (DOMÍNGUEZ et al., 2008).

In the international literature, human capital productivity has been a widely investigated topic, especially at the aggregate level. Sharma et al. (1990) showed that during the 1975-1980 period, the labor productivity of the agricultural sector was higher in developed countries than in countries in developing. Since the late 1970s, US and European consumers have enjoyed year-round availability of fresh grapes, pears, apples, and peaches in their local supermarkets - fruits that, in the winter months, come disproportionately from Chile (TINSMAN, 2003). The growth of export-oriented fruit production in Chile has increased the demand for labor, although mainly for temporary workers. Usually in the agricultural sector temporary workers are more numerous than permanent workers, and there are less social security benefits and less employment protection for temporary labor (GWYNNE, 1999). Ortiz and Aparicio (2007) pointed out that most new jobs created by the growth in horticultural exports have been unskilled low-wage jobs. This outcome supports the contention of many researchers and managers of successful companies that abundant 'cheap labor' was a necessity. However, 'cheap labor' could decrease competitiveness once the industry has consolidated its position in foreign markets. Schurman (2001) shows that the hyper-competition currently characterizing the agricultural export sector is putting pressure on companies to reduce costs, including labor costs. Chilean workers will have to be more productive; thus, new policies that increase productivity are required. The effects of these policies are influenced by the human capital characteristics of the hired labor.

Given the current scarcity of agricultural labor in Chile it is necessary to found strategies that improve labor performance especially in harvest season where the demand for labor increases notably. The aim of this article is to analyze a method for evaluating the quality of labor in cherry harvest in Chile and to evaluate this method using productivity indicators.

\section{MATERIALS AND METHODS}

The study was conducted between October 2010 and January 2011, in an area of the San Francisco de Mostazal in the Cachapoal Province,
Region VI, between 33'59' $\mathrm{S}$ and 7041' $\mathrm{W}$ at 503 m.a.s.l. (meters above sea level). We selected two plots within the orchard (see Table 1) and the quality of the hired labor at harvest time was evaluated.

Harvest labor evaluation system (HLES)

The harvest evaluation was performed using $10 \%$ of the production achieved by the workers during the day, (e.g. if the worker harvested 20 boxes, two were checked). A complete harvest period was evaluated for four seasons (2007/08; 2008/09; 2009/10 and 2010/11). The harvest period usually begin on November $20-25^{\text {th }}$ until December $15-20^{\text {th }}$ (roughly 20-25 days). Table 3 show a detail of mandays or Daily Work (DW) required for each season and for each plot evaluated. Since HLES requires a large number of workers, a quality control procedure for each team of workers was established, and a supervisor was appointed to go through the teams and oversee sampling. The evaluation focused on the quality of the fruit, and the parameters evaluated were chosen to ensure proper harvest of fruit in good condition, taking into account color, splitting, and blemishes, as detailed in Table 2 .

The steps for taking harvest evaluation samples were: 1) identifying the plot and harvest team; 2) taking the sample, which entails randomly choosing one box from the pallet containing the boxes harvested by the team, identifying the worker who harvested it, and weighing the box. From the chosen box, 100 fruits (equivalent to $10 \%$ of the fruit contained in the box) were randomly selected. These fruits were checked for defects (in accordance with Table 2), any defects founded were recorded in the quality control form, and the results were given to the team supervisor. A tolerance level of $80 \%$ of fruits without defects was set, i.e., up to 20 sampled fruits could be defective (ZOFFOLI, 2010). If at the end of the revision of the sample more than 20 fruits had defects, another box was immediately checked. If the result was negative again, the box was deducted from the worker's pay.

\section{Indicators and data analysis}

To analyze the effect of the harvest labor quality control described in section 2.1 , the productivity indicators described in Table 3 were established. These were subjected to a separate statistical analysis where the 2010/2011 (with HLES season) was compared to the 2009/2010, 2008/2009, and 2007/2008 (without HLES seasons).

With the Average Weight of Harvested Box (kg per box) and Average Daily Harvest per Worker (kg per DW and boxes per DW) indicators, an 
average comparison was done through a single factor analysis of variance (ANOVA, $p<0.05$ ) and a Tukey test with a confidence interval of $95 \%$. In the case of the Percent of Export Fruit and Percent of Fruit Discarded indicators, a simple comparison was done using descriptive statistics.

\section{RESULTS AND DISCUSSION}

Average Weight of Harvested Box

Table 4 shows significant differences $(p<0.05)$ in the Average Weight of Harvested Box in the different seasons both in the comparison of the separate plots and the plots as a whole. For the "Bing 99" plot, the 2010/11 season (HLES) has an average of $9.07 \mathrm{~kg}$ per box, and the largest difference was with the $2007 / 08$ season $(7.90 \mathrm{~kg}$ per box $)$, with $1.17 \mathrm{~kg}$ of variance, equivalent to $14.9 \%$. The $2008 / 09$ season had the smallest difference: $0.85 \mathrm{~kg}$, equivalent to $10.3 \%$. Regarding the "Bing 2001" plot, season $2007 / 08$ (7.74 kg per box) was the most different from the HLES season (9.02 $\mathrm{kg}$ per box) with 1.27 $\mathrm{kg}(16.4 \%)$, while the $2008 / 09$ season was the less different with $0.90 \mathrm{~kg}(11.0 \%)$. Overall, the HLES season had a positive effect on the Average Weight of Harvested Box, with at least $1 \mathrm{~kg}$ per box more than the rest of the control seasons. Additionally, increased filling of the boxes has an overall positive impact on the farm, i.e. savings in resources used in harvest labor such as boxes, pallets, and transport (tractor plus tractor workday).

Average Daily Production per Worker (kg per DW and boxes per DW)

Table 5 shows the Average Daily Production per Worker measured in kg per DW and boxes per DW. In the case of $\mathrm{kg}$ per DW, HLES season shows significant differences with the rest of seasons for both plots. In the case of the "Bing 99" plot, the 2009/10 season (101.31 kg per DW) has the largest difference compared to the HLES season (155.17 $\mathrm{kg}$ per DW), with $53.86 \mathrm{~kg}$ and 4.58 boxes less than HLES. For the "Bing 2001" plot, the 2008/09 season, with $94.32 \mathrm{~kg}$ per DW, was the most different from the HLES season. Relation to the measurement of boxes per DW in the "Bing 2001", there were significant differences in the 2008/09 and 2009/10 seasons relation to the HLES season ( 4.42 boxes and 2.04 boxes or, respectively). This was not the case with the 2007/08 season. The pooled analysis of both plots show that the 2008/09 season, for both the $\mathrm{kg}$ per DW and boxes per DW measurements ( $42.6 \mathrm{~kg}$ and 3.38 boxes, respectively), was most different from the HLES season, while the 2008/09 season was the less different.

The average output per worker was always higher in the HLES season, where the quality of labor evaluation method was applied to both the $\mathrm{kg}$ per DW and boxes per DW measurements. In cases where the difference was minimal or even zero (number of boxes harvested in the 2007/08 season), it was due to the effect of the harvested box average weight indicator, because in the 2007/08 season the content of the boxes ( $\mathrm{kg}$ per DW) was lower than in the 2010/11 season. This produced a decrease in average number of boxes harvested by workers (boxes per DW) in the 2010/11 season. This was not the case with the average number of kilograms harvested per worker.

Exports and Percent of Fruit Discarded

Table 6 shows the Percent of Export Fruit from the HLES season with previous seasons. The overall percent of export fruit for HLES season was $89.9 \%$ and it can be observed an increase of $3.7 \%$, $5 \%$, and $7.7 \%$ in relation to the $2007 / 08,2008 / 09$, and $2009 / 10$ seasons, respectively. Despite the fact that there were no statistical tests for this indicator, the export percentage for the 2010/11 season - in which the quality of labor evaluation was implementedwas always higher than for the previous seasons.

Table 6 also shows the results for the Percent of Fruit Discarded. For the "Bing 99" section, there is a slight decrease in this indicator in the most recent season from the 2007/08 season. The decrease from the 2008/09 and 2009/10 seasons to the 2010/2011 season is more pronounced. For the "Bing 2001" section, it is seen that the Percent of Fruit Discarded of the most recent season went down significantly from previous seasons. The Percent of Fruit Discarded of the HLES season, in which the quality of labor evaluation was implemented, was lower in every case. This improvement can be explained by the change made in the harvest structure: each team of workers had a quality control supervisor. Each worker had a better quality harvest, treating the fruit better and avoiding bruising, blemishes, and low caliber fruit, thus reducing the amount of discarded fruit.

Productivity and quality of hired labor in agriculture is undoubtedly a variable to which cherry producers must pay attention. Hired labor management is a helpful tool to achieve efficiency and productivity on the entire farm (BILLIKOPF, 2002). In this context, our results show improvements, such as: a) improvement in box filling, which positively impacted the use of inputs of the farm; b) the average output of workers improved or at 
least stayed constant, given the greater productivity required of them in the harvest; c) improvement in the quality of the fruit sent to processing, observed in the increase in the percent of fruit exports; and d) decrease in the percent of fruit discarded, at the same time as a decrease in the loss of potentially exportable fruit. These improvements are attributable to the implementation of the HLES method.

These results are in line with Billikopf (2002), who argues that the implementation of a labor performance evaluation can help improve labor productivity and enhance existing practices or establish new labor methods. Moreover, the information gained through the evaluations can also be used to create better job descriptions, plan training programs for already hired employees, and create other benefits that help the farm's performance (SALA \& SILVA, 2012). Also, training programs and labor programs are shown to have positive effects on the efficiency of hired labor in other sectors, such as the manufacturing and electronic sectors (MASON et al., 2012; YANG et al., 2010). HLES implementation implies a high investment in training (on-work) and its results showed an improvement in labor productivity indicators. The training "onwork" is suitable to acquire skills for a specific job while off-farm training is useful for acquire skills in any area (DEARDEN et al., 2006). Schonewille (2001) reveals that training has a positive effect on labor productivity but it is not clear whether this is mainly due to off-the-work or on-work training. In the industrial sector, Sepulveda (2010) found that training on-work increase productivity while training outside the company has no effect.

Retamales and Sepúlveda (2011) conclude that more investment in research, improvements in fruit quality, different orchard management practices, and higher financial support from the government are needed for the long-term viability of the fruit industry in Chile. Therefore investment in human capital could be a crucial strategy for improving productivity and competitiveness in the fruit sector (MUGERA et al., 2011). According to Martin and Mitra (2001), the lack of specialization could explain low rates of efficiency of the hired labor in the agricultural sector and training programs could help to fill this gap. However, agriculture has lower rates of training implementation than others sectors of the economy (CONTI, 2005); thus, specific "on-work" training programs should be implemented in order to analyze the relationship between productivity of hired labor and farm performance. Agriculture demands high labor-intensive production rather than mechanization or other inputs, and the most important cost item is hired labor. Therefore, gains in hired labor productivity could guarantee the sustainability and competitiveness of agricultural production (KESKIN et al., 2010). Lastly, these management efforts must be complemented by the introduction of new technologies to facilitate work in the orchards and to increase the productivity and competitiveness of the agricultural sector.

TABLE 1- Description of the plots selected for the study.

\begin{tabular}{lll}
\hline \multicolumn{1}{c}{ Plot name } & \multicolumn{1}{c}{ Bing 2001 } & \multicolumn{1}{c}{ Bing 99 } \\
\hline Plot size (Hectares) & 12.98 & 5.32 \\
Planting year & 2001 & 1999 \\
Variety/rootstock & Bing/Maxma 14 & Bing/Maxma 14 \\
Pollinator/rootstock & Rainier/Maxma 14 & Rainier/Maxma 14 \\
Planting areas (m) & $3 \times 5$ & $3 \times 5$ \\
Number of plants & 8,659 & 3,548 \\
Conduction system & Central axis & Central axis \\
\hline
\end{tabular}


TABLE 2-Main defects in cherries that influence the quality of the fruit.

\begin{tabular}{ll}
\hline \multicolumn{1}{c}{ Fruit defects } & \multicolumn{1}{c}{ Fruit defects } \\
\hline Low caliber & Spots \\
Soft & Splitting in stem cavity \\
Misshapen & Splitting \\
Dehydrated & Presence of spurs \\
Lack of color & Presence of fungus \\
Open wounds & Russet \\
Bruises & No pedicel \\
*Prepared with information from Ellena et al. (2006) and Zoffoli (2010).
\end{tabular}

TABLE 3- Productivity indicators and information sources.

\begin{tabular}{ll}
\hline \multicolumn{1}{c}{ Indicators } & \multicolumn{1}{c}{ Source } \\
\hline Average weight harvested box $(\mathrm{kg} \cdot$ per box $)$ & Producer information \\
Average daily production per worker $(\mathrm{kg}$ per DW and boxes per DW) & Producer information \\
Export percent & Packing information \\
Percentage of fruit discarded & Producer information \\
\hline
\end{tabular}

TABLE 4- Average weight of harvested boxes $\left(\mathrm{kg} \cdot \mathrm{box}^{-1}\right)$ sorted by season*

\begin{tabular}{lcccc}
\hline \multicolumn{1}{c}{ kg $\cdot$ box $^{-\mathbf{1}}$} & \multicolumn{4}{c}{ Season } \\
\hline & $\mathbf{2 0 0 7 / 0 8}$ & $\mathbf{2 0 0 8 / 0 9}$ & $\mathbf{2 0 0 9 / 1 0}$ & $\mathbf{2 0 1 0 / 1 1}$ \\
Bing 99 plot & $7.90 \mathrm{~d} \pm 0.16$ & $8.23 \mathrm{~b} \pm 0.20$ & $8.17 \mathrm{c} \pm 0.24$ & $9.07 \mathrm{a} \pm 0.11$ \\
Bing 2001 plot & $7.74 \mathrm{c} \pm 0.09$ & $8.12 \mathrm{~b} \pm 0.31$ & $7.95 \mathrm{c} \pm 0.28$ & $9.02 \mathrm{a} \pm 0.09$ \\
Both plots & $7.79 \mathrm{~d} \pm 0.13$ & $8.16 \mathrm{~b} \pm 0.27$ & $8.01 \mathrm{c} \pm 0.29$ & $9.03 \mathrm{a} \pm 0.10$ \\
\hline \multicolumn{5}{c}{ Overall savings of the farm } \\
\hline Boxes (units) & $\mathbf{2 0 0 7 / 0 8}$ & $\mathbf{2 0 0 8} / \mathbf{0 9}$ & $\mathbf{2 0 0 9 / 1 0}$ & $\mathbf{2 0 1 0 / 1 1}$ \\
Pallets (48 boxes) & 1,994 & 1,907 & 1,935 & 1,716 \\
Tractor (4 pallets) & 42 & 40 & 40 & 36 \\
\hline
\end{tabular}

*Different letters at same line indicate significant differences (Tukey's test, $p<0.05$ ). Standard deviation in italics. The data did not fulfill the normality and homogeneity assumptions, so a nonparametric Kruskal-Wallis test was performed, and the ranges were calculated and subjected to an analysis of variance (ANOVA, $\mathrm{p}<0.05$ ) and Tukey and Games-Howell tests, which yielded the same results.

TABLE 5- Average daily production per worker*.

\begin{tabular}{lllll}
\hline Kg per DW & $2007 / 08$ & $2008 / 09$ & $2009 / 10$ & $2010 / 11$ \\
\hline Bing 99 plot & $121.60 \mathrm{~b} \pm 26.79$ & $123.16 \mathrm{~b} \pm 31.82$ & $101.31 \mathrm{c} \pm 30.84$ & $155.17 \mathrm{a} \pm 39.21$ \\
Bing 2001 plot & $124.68 \mathrm{~b} \pm 34.06$ & $94.32 \mathrm{~d} \pm 33.07$ & $111.18 \mathrm{c} \pm 28.29$ & $144.59 \mathrm{a} \pm 38.85$ \\
Both plots & $123.80 \mathrm{~b} \pm 32.17$ & $105.06 \mathrm{c} \pm 35.45$ & $108.49 \mathrm{c} \pm 29.32$ & $147.67 \mathrm{a} \pm 39.24$ \\
\hline \multicolumn{5}{c}{ Boxes per DW } \\
\hline Bing 99 plot & $15.40 \mathrm{~b} \pm 3.37$ & $15.24 \mathrm{~b} \pm 3.86$ & $12.52 \mathrm{c} \pm 3.92$ & $17.10 \mathrm{a} \pm 4.33$ \\
Bing 2001 plot & $16.10 \mathrm{a} \pm 4.35$ & $11.61 \mathrm{c} \pm 4.18$ & $13.99 \mathrm{~b} \pm 3.50$ & $16.03 \mathrm{a} \pm 4.34$ \\
Both plots & $15.90 \mathrm{~b} \pm 4.10$ & $12.96 \mathrm{~d} \pm 4.42$ & $13.59 \mathrm{c} \pm 3.68$ & $16.34 \mathrm{a} \pm 4.36$ \\
\hline \multicolumn{5}{c}{ DW per season } \\
\hline Bing 99 plot & 531 & 316 & 270 & 560 \\
Bing 2001 plot & 1317 & 533 & 720 & 1361 \\
\hline
\end{tabular}

*Different letters at same line indicate significant differences (Tukey's test, $p<0.05$ ). Standard deviation in italics. The data did not fulfill the normality and homogeneity assumptions, so a nonparametric Kruskal-Wallis test was performed, and the ranges were calculated and subjected to an analysis of variance (ANOVA, $\mathrm{p}<0.05$ ) and Tukey and Games-Howell tests, which yielded the same results. 
TABLE 6- Percent of export and fruit discarded in the orchard.

\begin{tabular}{lcccc}
\hline & \multicolumn{4}{c}{ Season } \\
\hline \% of export fruit & $2007 / 08$ & $2008 / 09$ & $2009 / 10$ & $2010 / 11$ \\
Both plots & 86.71 & 85.64 & 83.47 & 89.90 \\
\hline & & & & \\
\% discarded in orchard & 0.90 & 1.60 & 2.30 & 0.75 \\
Bing 99 plot & 2.28 & 2.21 & 2.61 & 1.15 \\
Bing 2001 plot & 1.59 & 1.91 & 2.45 & 0.95 \\
Both plots & & & & \\
\hline
\end{tabular}

\section{CONCLUSIONS}

The results of this study case showed that the HLES for cherry crop improved the efficiency of workers, since significant differences were found between the HLES season (2010/11) and the previous seasons in terms of average worker output, measured in both kg per DW and boxes per DW.

In addition, the Percent of Export Fruits and Percent of Fruit Discarded indicators showed improvements in the HLES season, which was achieved with the same number of people as in previous seasons, i.e., fruit quality improved and the discarding of potentially exportable fruit decreased without requiring as many workdays.

Therefore, the implementation of HLES could improve the competitiveness of the export fruit sector, decreasing the labor costs as a result of a higher efficiency of the workers. Nevertheless, this method must be tested on other exports fruits to validate the results of this study case.

\section{REFERENCES}

ADASME-BERRÍOS, C.; ORTEGA-ROJAS, R.; RODRÍGUEZ-GUTIÉRREZ, M; LOBOSANDRADE, G. Identificación de constructos competitivos y estratégicos de las exportaciones de manzanas chilenas a los mercados asiáticos. Revista Brasileira de Fruticultura, Jaboticabal, v. 34, n. 2, p. 416-423, 2012.

ANDERSON, K.; VALDÉS, A. (Ed.). Distortions to agricultural incentives in Latin America. Washington: World Bank Publications, 2008.

BANCOCENTRAL. Estadísticas macroecónomicas de Chile. 2015. Disponível em: <http://www. bcentral.cl/estadisticas-economicas/>. Acesso em: 19 jan. 2015.
BILLIKOPF, G. Administración laboral agrícola: cultivando la productividad del personal. Berkeley: University of California, 2002. p. 262.

COMTRADE. World trade outlook. 2014. Disponível em: $\leq$ www.comtrade.un.org/>. Acesso em: 19 jan. 2015.

CONTI, G.; CONTI, G. Training, productivity and wages in Italy. Labour Economics, Netherlands, v. 12, n.4, p. 557-576. 2005.

DEARDEN, L.; REED, H.; VAN REENEN, J. The impact of training on productivity and wages: Evidence from British panel data. Oxford Bulletin of Economics and Statistics, Oxford, v. 68, n.4, 397-421, 2006.

DOMÍNGUEZ, J.I.; EBEL, P.; POBLETE, M.J. Características de la demanda de trabajo en el sector frutícola de exportación. Santiago: Oficina de Política Agraria y Departamento de Economía Agraria, Pontificia Universidad Católica de Chile, 2008. p. 23-54.

ELLENA, M.; AGUILERA, A.; FERRADA, S.; MONTENEGRO, A.; GUERRERO, J.; ROMBOLÁ, A. Cultivo del cerezo para la zona sur de Chile, Temuco, Chile. Carillanca: Centro Regional de Investigación Carillanca, Instituto de Investigaciones Agropecuarias, 2006. p. 195.

GABRIELE, B.; CONTINELLA, A.; GENTILE, A.; AMENTA, M.; FABRONI, S.; RAPISARDA, P. Fruit quality and bioactive compounds relevant to human health of sweet cherry (Prunus avium L.) cultivars grown in Italy. Food Chemistry, Reading, v. 140, n. 4, p. 630-638, 2013.

GWYNNE, R.N. Globalization, commodity chains and fruit exporting region in Chile. Tijdschrift voor Economische en Sociale Geografie, Utrecht, v. 90, n. 2, p. 211-225, 1999. 
KATZ, E.; MELO, O. Tipo de cambio y competitividad de la agricultura chilena. Santiago: Departamento de Economía Agraria, Pontificia Universidad Católica de Chile. Vicerrectoría de Comunicaciones y Asuntos Públicos, 2009. p.18.

KESKIN, G.; TATLIDIL, F.F; DELLAL, I. An analysis of tomato production cost and labor force productivity in turkey. Bulgarian Journal of Agricultural Science, Sofia, v.16, n.6, p. 692-699, 2010 .

MARTIN, W.; MITRA, D. Productivity growth and convergence in agriculture versus manufacturing. Economic Development and Cultural Change, Chicago, v. 49, n.2, p. 403-422. 2001.

MASON, G.; O’LEARY, B.; VECCHI, M. Certified and uncertified skills and productivity growth performance: Cross-country evidence at industry level. Labour Economics, Netherlands, v. 19, n.3, p. 351-360, 2012.

MELO, O.; REBOLLEDO, S. Productividad de los trabajadores agrícolas: Un análisis comparado para uva de mesa en Chile y España. In: CONGRESO REGIONAL DE ECONOMISTAS AGRARIOS, 2., 2008. Montevideo. Anales... p. 1-5.

MUGERA, A.W.; LANGEMEIER, M.R.; FEATHERSTONE, A.M. Labor productivity convergence in the Kansas farm sector: a threestage procedure using data envelopment analysis and semiparametric regression analysis. Journal of Productivity Analysis, Netherlands, v. 38, n 1, p. 63-79, 2011.

ODEPA. Agricultura Chilena 2014: una perspectiva de mediano plazo. 2014. Disponível em: <http:// www.odepa.cl/odepaweb/servicios-informacion/ publica/Agricultura2014.pdf $>$. Acesso em: 19 jan. 2015.

ODEPA. Estadística de la agricultura chilena: estadísticas geoeconómicas, empleo del sector. Oficina de Estudios y Políticas Agrarias, 2011a. Disponible em: $<$ http://www.odepa.cl $>$. Acesso em: 21 abr. 2011 b.

ODEPA. El mercado de fruta fresca 2010. 2011 b. Disponível em: <http://www.odepa.cl/odepaweb/ publicaciones/doc/2474.pdf $>$. Acesso em: $21 \mathrm{abr}$. 2014.
ODEPA. Panorama de la agricultura chilena. 2009.

Disponível em: < http://www.odepa.cl/wpcontent/ files_mf/1401805441Panorama_agricultura chilena_2009.pdf >. Acesso em: 21 abr. 2014.

ORTIZ, S.; APARICIO, S. How Laborers Fare in Fresh Fruit Export Industries: Lemon Production in Northern Argentina. Journal of Agrarian Change, United Kingdom, v. 7, n. 3, p. 382-404. 2007.

RETAMALES, J.B.; SEPÚLVEDA, J. Fruit production in Chile: Bright past, uncertain future. Revista Brasileira de Fruticultura, Jaboticabal, v.33, n.1, p.173-178, 2011.

ROJAS, C.; OPITZ, R.; GUERRERO, A.; GUTIÉRREZ, A. Evolución de las Exportaciones silvo-agropecuarias de Chile a sus Socios Comerciales (2000 to June 2010). Santiago: Oficina de Estudios y Políticas Agrarias, 2010. 65 p.

SALA, H., SILVA, J.I. Labor productivity and vocational training: evidence from Europe. Journal of Productivity Analysis, Netherlands, v. 40, n.1, p. 31-41, 2012.

SCHONEWILLE, Mark. Does training generally work? Explaining labour productivity effects from schooling and training. International Journal of Manpower, United Kingdom, v. 22, n. 1/2, p. 158$173,2001$.

SCHURMAN, R.A. Uncertain gains: labor in Chile's new export sectors. Latin American Research Review, Austin, v. 36, n.2, p.3-29, 2001.

SEPÚLVEDA, F. Training and productivity: evidence for US manufacturing industries. Oxford Economic Papers, United Kingdom, v. 62, n. 3, p. 504-528, 2010.

SHARMA, K. C.; PRASADA RAO, D.S; SHEPHERD, W.F. Productivity of Agricultural Labour and Land: An international Comparison. Agricultural Economics, Durban, v.4, n.1, p. 1-12, 1990.

TINSMAN H. Women and agribusiness: Working miracles in the Chilean fruit export sector. International Labor and Working-Class History, Los Angeles, v. 64, p.198-201, 2003. 
WANI, A.A.; SINGH, P.; GUL, K.; WANI, M.H.; LANGOWSKI, H.C. Sweet cherry (Prunus avium): Critical factors affecting the composition and shelf life. Food Packaging and Shelf Life, Freising, v. 1, n.1, p. 86-99, 2014.

YANG, C.-H., LIN, C.-H., MA, D. R\&D, Human Capital Investment and Productivity: Firm-level Evidence from China's Electronics Industry. China World Economy, Beijing, v. 18, n.5, p. 72-89, 2010.
YILMAZ, K. U.; ERCISLI, S.; ZENGIN, Y.: SENGUL, M.; KAFKAS, E. Y. Preliminary characterisation of Cornelian cherry (Cornusmas L.) genotypes for their physico-chemical properties. Food Chemistry, Reading, v. 114, n. 2, p. 408-412. 2009.

ZOFFOLI, J.P. Manejo de los puntos críticos para optimizar la calidad de postcosecha de cerezas. In: SEMINARIO DE CEREZAS DE LAASOCIACIÓN DE EXPORTADORES DE CHILE, 2010, Santiago. Anales... 